\title{
Phenomenological Life-World Analysis and Ethnomethodology's Program
}

\author{
Thomas S. Eberle
}

Published online: 26 April 2012

(C) Springer Science+Business Media B.V. 2012

\begin{abstract}
This paper discusses ethnomethodology's program in relation to the phenomenological life-world analysis of Alfred Schutz. A recent publication of Garfinkel's early writings sheds new light on how he made use of phenomenological reflections in order to create a new sociological approach. Garfinkel used Schutz's life-world analysis as a source of inspiration, called for 'misreading' in the sense of an alternate reading and developed a new, empirical approach to the analysis of social order which he called 'ethnomethodology'. Ethnomethodologists usually acknowledge the historical importance of Schutz but emphasize that Garfinkel succeeded to overcome the limitations of phenomenological analyses and moved beyond. This view has spread above all in the Anglosaxon countries. In German sociology, Schutz's life-world analysis still has a much stronger standing than ethnomethodology and is interpreted as a systematic whole. Following Luckmann, it is discussed as a protosociological foundation of the methodology of social sciences or, following Srubar, as a philosophical anthropology with two poles: a subjective and a social, pragmatic pole. Both versions claim to analyze the meaningful constitution of the social world, to serve as a foundation of sociological methodology and to provide guidelines for an 'adequate' sociology. While Garfinkel used phenomenological concepts for sociological analysis, Luckmann clearly distinguishes the two: you either do phenomenology (protosociology) or you do sociology (a theoretically guided, empirical sociology of knowledge). This paper describes the present-day debate in German sociology and compares ethnomethodology's program with these interpretations of Schutz's life-world analysis.
\end{abstract}

Keywords Life-world analysis · Phenomenology · Phenomenological sociology · Ethnomethodology $\cdot$ Protosociology $\cdot$ Philosophical anthropology

T. S. Eberle $(\bowtie)$

Institute of Sociology, University of St. Gallen, 9000 St. Gallen, Switzerland

e-mail: thomas.eberle@unisg.ch 


\section{Introduction}

The life-world analysis of Alfred Schutz was received by sociologists in quite different ways. Two prominent and fundamentally different approaches are Berger and Luckmann's Social construction of reality (1966) and Garfinkel's Studies in ethnomethodology (1967). Both represent, in Psathas' (1989) broad sense, a 'phenomenological sociology,' but they make quite different uses of phenomenology: Berger and Luckmann, on the one hand, distinguish sharply between phenomenology and sociology on methodological grounds: you do either phenomenology or sociology - these are two different enterprises but they can be related in a sociology of knowledge approach. Garfinkel, on the other hand, used phenomenology as a source of inspiration to create a new sociological approach that explains social order. These two positions can be seen as poles that limit the field of phenomenological sociology; there are manifold further positions of combining phenomenology and sociology that lie in between.

The relationship between phenomenology and ethnomethodology is usually portrayed in the way that Schutz's seminal work inspired Garfinkel to create an alternative approach to explain the problem of order than the one of his mentor Talcott Parsons. In the eyes of ethnomethodologists, Garfinkel has succeeded to overcome the limitations of Schutz's phenomenological analyses and to move beyond. For them, Schutz's work is nowadays only of historical relevance; therefore, young ethnomethodologists are usually not anymore familiar with it. I am going to tell a different story here: In my view, Schutz's life-world analysis provides a fruitful frame for assessing the scope of ethnomethodology and for interpreting its findings. Ethnomethodologists contributed substantially to an empirical exploration of the life-world but the Schutzian approach is broader and more apt to theoretically integrate the different studies.

I may add that this is not just my personal opinion but one that is widely shared in German sociology. Ethnomethodology disseminated much more in the Anglosaxon world than in the German speaking countries. In the latter, many more sociologists still adhere to Schutz's phenomenological life-world analysis and to the sociology of knowledge as devised by Berger and Luckmann, than to ethnomethodology. There are many different reasons for this. One may be that US sociology has a stronger empirical tradition while German sociology is earmarked by a preference for theoretical and methodological debates. Another reason may be that ethnomethodology originated in California and spread from there while Luckmann taught in Germany and exerted a strong impact on German sociology. Both these factors mutually reinforced each other and there may be, of course, also further reasons for these different prevalences.

In order to unfold my argumentation I am going to start with the goal and the results of Schutz's life-world analysis, which I will describe in its subjective as well as in its pragmatic aspects. Then I am going to outline how Garfinkel's program of ethnomethodology differs from Schutz's approach, and I will close with a conclusion that calls for a reconsideration of the relationship between phenomenology and ethnomethodology. 


\section{Schutz's Project of a Life-World Analysis}

Schutz (1967) states the goal of his life-world analysis quite clearly: to provide a philosophical foundation of Max Weber's ([1922] 1978) approach of an actionbased interpretive sociology. He agreed with the members of the Vienna Circle that logical consistency is an important methodological postulate for the social as well as for the natural sciences, but he was aware that logics alone would not suffice. In contrast to Carnap's Logical Structure of the World ([1928] 1967) he emphasized the meaningful structure of the social world (1967) that any methodology of the social sciences has to take into account. In Schutz's view, Weber had conceived a convincing, interpretive approach that defined it as the sociologist's primary task to understand the sense (meaning) of social action. Schutz detected several equivocations in Weber's methodological reflections and set out to eliminate them by carefully analyzing and describing the meaning structures of the life-world, the constitution of sense in an actor's experience, the process of understanding the other in various kinds of social (spatial and temporal) relationships, and the difference and relation between the common-sense constructions in everyday life and the constructions of the social scientist (i.e., of first and second order constructs). The most systematic, concise and thorough argumentation can still be found in Schutz's early book (the translation into English is unfortunately rather unsatisfying). In spite of the manifold ramifications and diverse topics of his later work, this basic goal remained the same throughout Schutz's life. This is well demonstrated by Schutz's plan to sum up his findings in his two-volume book The Structures of the LifeWorld, its table of contents, and his index cards. Luckmann's posthumous edition of this book in two volumes differs in some aspects from the original plan as Luckmann acted as co-author, but it manifests how rich, detailed, and systematic Schutz's life-world analyses altogether were (Schutz and Luckmann 1973, 1989). Luckmann's decision to omit the final chapter on methodology from this edition was, however, not so fortunate as Schutz's original goal to elaborate a philosophical foundation of the methodology of the social sciences thereby was lost sight of.

The Phenomenological Life-World Analysis

Schutz's early work pondered the "forms of life," analyses that were significantly influenced by Henri Bergson (Schütz 2006). Motivated by Felix Kaufmann, Schutz began to study the phenomenology of Edmund Husserl who had developed the phenomenological method, the constitutive analysis and later the concept of 'lifeworld'. Husserl intended to remedy the Crisis of the European Sciences ([1936] 1970) by a phenomenological life-world analysis. He argued that the sciences had begun to take their idealizations and abstractions as 'the real being' and that their origin in the natural acts of apperception ('Anschauung') had been lost. A phenomenological analysis of the life-world would explicate this foundation of the sciences and thereby solve their crisis. Schutz envisaged a similar project for the social sciences. He did not talk of a "crisis" of the social sciences but he was convinced that they were in dear need of a philosophical foundation. As Husserl only meant the natural sciences and their mathematical constructions when talking 
of "sciences," Schutz had to find his own way to develop a phenomenological lifeworld analysis that would serve the social sciences.

Schutz built on many insights of Husserl and contended that the phenomenological insights that were gained in the reduced sphere of the 'transcendental reduction' are also valid in the realm of the natural attitude. But Schutz saw clearly that in order to provide the social sciences with a proper foundation, additional phenomenological analyses were needed in the mundane sphere. Even more crucial was his dismissal of the "picture book phenomenology" of some of Husserl's students, as Edith Stein or Gerda Walther, who used the eidetic method in a rather naïve way when "analyzing the problems of social relations, of community, and of the state" and formulated "certain apodictic and purportedly aprioristic statements which have contributed toward discrediting phenomenology among social scientists" (Schutz 1962: 140-141).

Schutz took a different road when advocating a constitutive analysis of the life-world. He followed Scheler (1922) and saw his task in developing a philosophical anthropology. He concludes "that the empirical social sciences will find their true foundation not in transcendental phenomenology, but in the constitutive phenomenology of the natural attitude" (Schutz 1962: 149). Schutz found the link between phenomenology and sociology in the subjective sense (meaning) of social action. Sociology is, as Max Weber had shown, a science that understands and explains social action. All phenomena of the socio-cultural world originate in social action and can be traced back to its subjective sense (meaning). Phenomenology starts its life-world analysis with the subjective sense, too, namely with the meaning structures as found in the lived experience of actors. Like Husserl ([1936] 1970), Schutz attempts to describe the universal and invariant formal structures of the life-world. A philosophical anthropology must refer to the conditio humana per se, i.e., to any human being on this earth. As such it can serve as a tertium comparationis and allows to relate specific historical and cultural observations to these fundamental formal structures that are the same for everyone. Philosophical anthropology and sociology therefore have different tasks: The task of a phenomenological life-world analysis is to explicate the universal and invariant formal structures of the life-world, and the task of the empirical social sciences is to research the historical and cultural variety of concrete situations. For an illustration: Every ("normal") actor on earth makes sense by use of his or her subjective stock of knowledge at hand, applies typifications, is guided by systems of relevances, orients in time and space and relies on systems of appresentation in order to understand the other or to relate to transcendent realities. The concrete contents of knowledge, however, the concrete types that are used and the concrete relevances that are enacted, and so on, are culturally and historically contingent—-their research is therefore the task of empirical sciences.

In this vein, Luckmann $(1973,1979)$ designates the phenomenological analysis of the formal structures of the life-world as a "protosociology" and distinguishes it sharply from "sociology". A phenomenological analysis is genuinely different from a sociological analysis:

1. Phenomenology is a philosophy. Its goal is to describe the universal structures of subjective orientation in the life-world. It therefore analyses phenomena of 
subjective consciousness. Its perspective is egological and its method proceeds reflexively.

2. Sociology is a science. Its goal is to explain the general properties of the objective world. It therefore analyses phenomena of the social world. Its perspective is cosmological and its method proceeds inductively.

Luckmann interprets the universal and invariant structures of the life-world as a mathesis universalis, a formal matrix that will allow solving the problem of measurement in the social sciences. By means of this matrix, propositions that are formulated as empirical observations in a certain cultural and historical language can get translated into a formal language. It is the specific characteristics of the phenomenological method that makes such a matrix possible: the phenomenological reduction elucidates in incremental acts of reflection the conditions of its own method, the conditions of the provided evidence, and the conditions of communicating this evidence to others. Schutz has, in Luckmann's view, succeeded in providing the scope of such a protosociological matrix, while its details may be scrutinized through further phenomenological analyses.

Luckmann's sharp distinction between phenomenology and sociology is based upon methodological grounds. You either do phenomenology or you do sociology but there cannot exist such a thing as a 'phenomenological sociology' (cf. Eberle 2012). If you do phenomenology you do protosociology, meaning you work on the philosophical foundation of the methodology of the social sciences. But of course, sociology should methodologically relate to this protosociology, the sociological concepts and theories must be compatible with the structures of the life-world. This implies, for instance, a preference for methodological individualism and, much more, a dispreference for holistic constructions. Berger and Luckmann (1966) developed a sociological theory that is based on Schutz's life-world analysis. The Social Construction of Reality consists of three parts: (1) The foundations of knowledge in everyday life; (2) Society as objective reality; and (3). Society as subjective reality. In the first part the two authors present some key results of Schutz's phenomenological analysis of the life-world and call them explicitly "philosophical prolegomena" that are "presociological" and "not scientific" (1966: 20). But they consider them as an apt "starting point for sociological analysis" (ibid.). Based on these protosociological considerations, they design a new sociology of knowledge that consists of two perspectives: "Society as objective reality" contains analyses of the processes of institutionalization and legitimation; "Society as subjective reality" treats processes of internalization and the evolvement of identity. The theoretical reflections in this book provide ample demonstrations and inspirations of how Schutz's findings can be seminally used for sociological analysis and how other sociological theories can be re-interpreted in their light. The analytical potential of this theory of knowledge still awaits full exploitation (Endress 2008).

It comes as no surprise that Peter L. Berger, like Luckmann, argues against the amalgamation of phenomenology and sociology in an enterprise called 'phenomenological sociology'. In an exchange with Tyriakian $(1965,1966)$ in the ASR, Berger (1966) criticizes Tyriakian's way of trying to "synthesize" phenomenology 
and sociology. This happened at a time when-as Bird (2009) points outphenomenological sociology was treated quite peripherally by mainstream sociology and when many of the arguments that were put forward were primarily strategic. Later on, Berger left the methodological reflections on phenomenology and sociology to Luckmann. He did not consider himself a phenomenological sociologist but preferred labeling his own approach 'a humanistic sociology' (Berger 1963). ${ }^{1}$

\section{The Pragmatic Life-World Theory}

As Ilja Srubar $(1988,2007,2009)$ has convincingly shown, there is more to Schutz than a phenomenological analysis of the intentional processes in the subjective consciousness. Schutz's life-world analysis has not only a subjective but also a pragmatic, social pole: The life-world is not only perceived and experienced in subjective consciousness; it is also constituted by pragmatic social actions. Srubar already detects this "pragmatic turn" (1988) in Schutz's early writings and proves the previous biographical interpretation wrong that Schutz began to integrate concepts and ideas of American pragmatists after his move to the United States in order to obtain better acceptance. Schutz complemented, in Srubar's wording, Husserl's 'paradigm of perception' by a 'paradigm of action': a human being is not only ego cogitans but also ego agens. The pragmatic life-world theory encompasses both: the subjective as well as the pragmatic pole, and the two are related to each other.

Throughout his life, Schutz proceeded consistently with a phenomenological approach. Time and again, he reached impasses that evoked doubts about the potential of a transcendental phenomenology. He judged Husserl's attempt to clarify intersubjectivity in the transcendental sphere as insufficient and finally as not feasible, and considered intersubjectivity as "the fundamental ontological category of human existence in the world and therefore of all philosophical anthropology" (CPIII: 82). The late Schutz also casted doubts on the eidetic reduction: In his late essay Type and eidos in Husserl's late philosophy (CPIII: 92-115) he stated that phenomenological ideation in search of the eidos "can reveal nothing that was not preconstituted by the type" (CPIII: 115). Schutz realized that his mundane, pragmatic theory of the life-world was a legitimate counterpart of transcendental phenomenology and emphasized the primacy of the pragma: it is sociality that founds subjectivity, not the other way around (Srubar 1988: 266). The interaction in a we-relationship represents the heart of mundane sociality, and thinking is derived from communication (in accordance with Mead).

The exegesis of Schutz's work usually focused on phenomenology and overlooked the importance of its pragmatic side. Srubar (1988, 2007, 2009) systematically carved out these pragmatic aspects and analyzed them in many publications. Consequently, he does not speak of a 'phenomenological life-world analysis' but of Schutz's 'pragmatic life-world theory'. This has a subjective as well as a pragmatic, social pole, and both are interconnected by Schutz's theory of appresentative systems (i.e., apperceptual, appresentational, referential and contextual scheme). The life-world is a material, cultural world-Srubar (1988) uses, like

\footnotetext{
${ }^{1}$ For more information cf. Psathas (2004) and Pfadenhauer (2010).
} 
Schutz, Voegelin's notion of 'Kosmion' - and is on the one hand a social reality and on the other hand a subjective reality. In the subjective experience the social reality appears as structured in different spatial, temporal and social zones, and there are always subjective attitudes to socially imposed relevances. At the same time these subjects (individuals) were socialized and enculturated by their society. Acting subjects are also able to transcend their zone of operation and experience different provinces of meaning, like the worlds of imagination or of dreams. At the same time these provinces of meaning also have a social counterpart in knowledge systems of transcendent realities (philosophy, religion, science, art). The linguistic and symbolic systems of appresentation that allow for such transcendences are also of social origin. Their crucial function is that they interconnect subjective experience with social communication.

Srubar's reinterpretation of Schutz's life-world analysis counters prominent criticisms by Habermas and Luhmann who reduced Schutz's approach to an analysis of subjective consciousness. Schutz pursued not only a subtle analysis of an actor's subjective perspective and of experiences that transcend the paramount reality of everyday life; he also provided a theory of the autogenesis of social order in interactions. And his theory of appresentation explicates how the pole of subjective experience and the pole of social communication are interconnected. The pragmatic life-world theory of Schutz thereby acquires the same theoretical status as the foundational approaches of Habermas or Luhmann, and even one that seems better suited: a theory of constitution that escapes the analytical limitations of speech-act theory (Habermas) as well as the aporia of the mutual exclusion of the psychic and the social system (Luhmann). The pragmatic life-world theory-Srubar calls it a "theory," presumably due to its theoretical status and scope-shares many basic premises with symbolic interactionism, and some with ethnomethodology as well as with Luhmann's systems theory.

What is the relationship between the pragmatic life-world theory and sociology? As the life-world in this version has not only a subjective but also an pragmatic, social pole, Luckmann's clear-cut distinction between the egological perspective of phenomenology and the cosmological perspective of sociology does not apply anymore. Indeed, Srubar does not distinguish between phenomenological protosociology and cosmological sociology. He draws a different line, namely between theories of constitution and empirical studies of society. In accordance with Luckmann, he considers Schutz's pragmatic life-world theory as a philosophical anthropology and as such as a basic formal matrix and a tertium comparationis that allows for comparing different cultures. Schutz's theory of constitution describes the human reality as an interlinking of life-worlds with a multiplicity of perspectives and manifold realms of meaning, and it systematically takes into account the variability of cultural worlds and of different life-forms. As opposed to Luckmann's concept, Srubar (1998) considers this matrix not as static; the constitutive mechanisms are rather seen as the generators of the dynamics, historicity and differentiation of the life-world. Srubar (2005) shows why and how the pragmatic life-world theory has more potential to facilitate adequate cultural comparisons, than have concepts that evolved in a specific scientific discourse (as, for instance, the dimensions used by Hofstede 1997). 


\section{Ethnomethodology's Program}

\section{Garfinkel and the Phenomenologists}

In his Studies in Ethnomethodology Garfinkel (1967: ix) mentions one sociologist and three phenomenologists as his intellectual mentors: Talcott Parsons, Alfred Schutz, Aaron Gurwitsch and Edmund Husserl. He already came into contact with phenomenology during his master's studies at the University of North Carolina at Chapel Hill from 1939 to 1942 when he read texts of Husserl, Gurwitsch and Gestalt-psychologists (Garfinkel 2002: 82ff; Rawls 2002: 11ff). As Psathas (2009) reports he even took phenomenological writings to the army where he served from 1942 to 1946. In 1946 he began his Ph.D.-studies with Talcott Parsons at Harvard where he stayed until 1951. During this period he established a relationship with Aron Gurwitsch whom he visited in his house on a regular basis. And he often travelled to New York to spend tutorial evenings with Alfred Schutz (Garfinkel 2002: 84). Through these relationships his interest in phenomenology became deeper and more profound (Rawls 2002: 15). Garfinkel produced two significant texts in this period that show how his reflections emerged between Parsons' structural functionalism on the one hand and phenomenology on the other: his study Seeing sociologically (Garfinkel [1948] 2006) and his dissertation The perception of the other: a study in social order (Garfinkel 1952). While his dissertation remained unpublished, a copy from microfiche was available at the library of Harvard University. Garfinkel's previous text with the clumsy title Prospectus for an Explanatory Study of Communicative Effort and the Modes of Understanding in Selected Types of Dyadic Relationships, however, was most widely unknown and only recently detected by Anne W. Rawls in Garfinkel's archives. Rawls published it in 2006 (Garfinkel 2006) and called it "a proposal for a dissertation that was never written" (Rawls 2006: 2). This text was fabricated in 1948 and fell, according to Rawls, "into the hands of several key thinkers early on: Erving Goffman, Anselm Strauss, and Harvey Sacks among them" (Rawls 2006: 2). Both texts contain extensive theoretical discussions on the adequacy of theoretical premises and sociological concepts and provide much of those theoretical clarifications and background reflections which many had wished to get from Garfinkel, but which to give he persistently refused later on.

The influence of phenomenology on Garfinkel and his ethnomethodology was thoroughly analyzed (e.g., Heritage 1984; Lynch 1993, 2004; Sharrock 2004; Psathas 1989, 2004, 2009; and in German: Eberle 1984, 2000), but not on the basis of this hitherto unknown text. In Seeing sociologically, Garfinkel (2006) reflects on some basic theoretical notions, like action, actor, role and the concept of the finite province of meaning, the noesis-noema structures, social identity, identity constancy and identity transformation, communication, style, tactics and strategies of communication, and group. In addition, he ponders on how to design an experiment that would provide empirical insights (as he did in his dissertation, too). As this text reveals how much Garfinkel was inspired by phenomenology when developing his own approach, I will take a closer look at it, focusing on some basic aspects (see also Eberle 2008). 
From an Egological Perspective to an Observer's Perspective

Husserl's phenomenology takes the ego-cogito-cogitatum, i.e., the intentionality of subjective consciousness as a starting point and analyzes the modes of givenness of phenomena in their noetic and noematic aspects. The sense (meaning) of phenomena gets constituted by polythetic acts in the temporal stream of subjective consciousness. Schutz adopted these analyses and pursued them further in order to clarify the meaning structure of the social world. Relating to Weber's conception of sociology, he emphasized the temporality as well as the perspectivity of meaning constitution: One must discern the differences between the diverse levels of meaning, between subjective and objective sense connections, between interpretation of one's own actions and the interpretation of others, and between the perspectives of others in the variety of their different spatial and temporal modes of givenness. Schutz also pondered on the transcendences: transcending the here and now by idealizations, transcending one's body and mind by understanding the other, or transcending everyday life by entering other finite provinces of meaning. The life-world analysis of Schutz is, as we have seen, a mundane phenomenology of the natural attitude and has two poles: a subjective one and a pragmatic, social one. As we will see, Garfinkel focuses on the pragmatic, social pole.

In Seeing sociologically Garfinkel cites Husserl and Schutz many times, Gurwitsch twice. In relation to the mundane phenomenology of the natural attitude, he grounds his reflections exclusively on Schutz's essay On multiple realities (1945). In contrast to Schutz, his sociological frame of reference is not the action theory of Weber but that of Parsons. Garfinkel's declared goal is "seeing things anew" (2006: 101) or, as became clearer later on, developing a new sociological perspective by means of phenomenology:

First, the leading aim of this project is to translate the concept of social relationship into the terms of communicative efforts between actors. Second, our problem is to study this communicative endeavor with regard to its contents, organizations of meanings, the processes and logics of communicative expressions, and the tactics of communication and understanding using the fact that the experience of incongruity can be experimentally induced as the means for teasing these various facets out of the closely woven fabric of social intercourse (Garfinkel 2006: 99f.).

Garfinkel, in other words, already developed the objective and the methodical procedure of incongruity experiments as a graduate student at the age of 31. Like Weber and Parsons, he starts with social action and ponders on what "seeing sociologically" can mean. How can a sociological observer relate to his data? How is it possible that the world is a fact? He suspends discussing the meaning of such central notions like 'existence,' 'reality,' and 'objectivity' and adopts a phenomenological perspective: "We shall refer instead to the phenomenological researches of Edmund Husserl, and accept his views with regard to the considerations involved for the scientist who seeks a radical and rational empiricism" (Garfinkel 2006: 102). Garfinkel accepts, citing Husserl, "that the world in fact consists of nothing else than these noesis-noema structures" (2006: 141). His whole argumentation, 
however, rests much less on Husserl's transcendental phenomenology than on the mundane phenomenology of the natural attitude by Schutz. He quotes many excerpts from Schutz's On multiple realities in which the actor's perspective in the paramount world of everyday life, the understanding of the other and the construction of actions by a scientific observer are discussed. The focal point is the meaningful structure of the social world or, as Garfinkel (2002) will formulate later, the problem of meaning. In contrast to behaviorism-but also to other sociological approaches that treat social meanings as intersubjective on the basis of a shared system of symbols-Garfinkel emphasizes, following Schutz, the diversity of meanings and the importance of interpretive acts.

Many of Schutz's analyses of the modes of givenness of social phenomena proceeded in an egological perspective, and many emphasized the noetic aspect of subjective experience. But from early on, he made concisely clear that the noematic aspect of social phenomena consists of social actions and therefore analyzed in detail how the other is constituted and how he and his actions can be understood: There is no direct access to the other's mind and the alter ego's experiences; it must be mediated by appresentative systems, such as marks, indications, signs and symbols. Bodily movements, human 'behavior,' can be observed and get interpreted as meaningful "actions" by sensemaking. Schutz describes the mechanism of communication from the standpoint of the actors who enact bodily behavior and reciprocally make sense of it. In the cited essay $O n$ multiple realities, Schutz not only distinctly describes the subjective, but also the pragmatic pole of his life-world analysis and describes it as mundane, intersubjective and unquestioned. The social world of everyday life is constituted by social actions, and this implies reciprocal interactions in which each actor communicates and interprets the communication of the other.

Subjective experience represents the subjective pole of Schutz's life-world analysis, social interactions represent the pragmatic, social pole. Garfinkel is less interested in an egological analysis of subjective experience but much more, as a sociologist, in a careful analysis of social actions in everyday life. He develops an empirical sociological program in an observer's perspective and points out that actors make their actions observable, tellable, reportable or-in his famous wording - 'accountable'. It is the 'communicative efforts' of actors that make actions recognizable, interpretable and intelligible. The task of ethnomethodology is, as he formulates later on, to analyze the methods, or the practices, with which such a concerted sense-making in its temporal sequence is achieved.

Garfinkel explicitly embarks on the pragmatic, social pole of Schutz's life-world analysis. He is only interested in what is empirically observable, i.e., in social actions. What happens in the head or in the subjective consciousness of an actor remains hidden to the observer and is therefore regarded as irrelevant. This is a significant departure from Schutz's approach. Schutz always assumed that the motives of an actor can be understood by another actor in principle, if only approximately. In the perspective of ethnomethodology it can be observed that actors attribute or ascribe motives to each other, but this is only of interest as a matter of communicative acts and of concerted sense-making. Garfinkel follows Parsons who separated the personal system from the social system and defined the sociologist's task to focus on the social system. Accordingly Garfinkel states: 
I shall exercise a theorist's preference and say that meaningful events are entirely and exclusively events in a persons' behavioral environment ... Hence there is no reason to look under the skull since nothing of interest is to be found there but brains. The 'skin' of the person will be left intact. Instead questions will be confined to the operations that can be performed upon events that are 'scenic' to the person" (Garfinkel 1963: 190).

This is a wonderful argument against recent attempts of neuroscience to link brain functions with realms of meaning. On the other hand, neither Parsons' structural functionalism nor Niklas Luhmann's systems theory have denied that the subjective consciousness as well as the social system both operate with meaning. There is a significant accordance between Garfinkel and Luhmann as the latter, too, argues that sociological analysis must be restricted to social communication (Luhmann ([1984] 1995). One of the differences, however, is that Luhmann's grand theory also describes systems of consciousness (which in this theory belong to the environment of the social system, or more specifically, of the communication system) ${ }^{2}$ while Garfinkel dismisses the term of consciousness completely. But there are further commonalities of Garfinkel and Luhmann, as for example the elimination of anthropological premises.

\section{The Elimination of Anthropological Premises}

As was argued above, Schutz advocated a mundane phenomenology of the natural attitude and a philosophical anthropology because he became skeptical of the potential of transcendental phenomenology. He realized the shortcomings of the transcendental as well as of the eidetic reduction and already dispensed in the Phenomenology of the social world with the epoché, the bracketing of generally accepted assumptions of the natural attitude. He posited the general thesis of the existence of the alter ego, and added further anthropological premises later on. While Husserl insisted that the transcendental ego was not synonymous with the ego of a human being, Schutz did not only refer to the cognizing subject per se but to human individuals with their bodies and their consciousness, and in their sociality and historicity. This is manifested by many of Schutz's concepts, like human action, biographically determined stock of knowledge at hand, biographically determined hierarchy of plans, our knowledge and fear of dying as the fundamental anxiety (Heidegger) from which "spring the many interrelated systems of hopes and fears, of wants and satisfactions, of chances and risks which incite man within the natural attitude to attempt the mastery of the world, to overcome obstacles, to draft projects, and to realize them" (Schutz 1962: 228), as well as, finally, his famous proposition that "as long as human beings are not concocted like homunculi in retorts but are born and brought up by mothers, the sphere of the 'We' will be naively presupposed" and is, as Scheler asserted, "pregiven to the sphere of the I" (Schutz 1962: 168).

In this respect Garfinkel differs distinctly from Schutz: He dismisses all anthropological premises. Actors in the ethnomethodological perspective are no concrete individuals with flesh and blood, who act on the basis of their intentions,

\footnotetext{
${ }^{2}$ As the personality system belongs to the environment of the social system in Parsons' (1966) general action system.
} 
play different roles in different settings and who have a self or a personal identity, a biography or plans for their future. Actors are rather meaningful constructions that are produced in a given sequence of interaction. Put laconically: For ethnomethodology there exist no actors but only actions. It is not actors that produce actions but rather actions that produce actors. Many non-ethnomethodologists have misunderstood this point and connoted the notion of Garfinkel's actor with the premises of methodological individualism and/or the ontological assumptions of the natural attitude; they assumed that actors are human beings who enter a situation and act and communicate in it.

Actors are no persons (Garfinkel 2006: 186) but identities that are constructed by situated actions. Later on Garfinkel introduced the concept of 'member' (1967: 76), which, in Parsons' sense, implies membership in a collectivity. He thereby reduced the inclination to reify actors as individuals or human beings. Deciding if someone is a member is not up to the scientific observer but rather to the other members of the collectivity: A member is who is accepted as a 'member' in interaction, and this is empirically observable.

Garfinkel not only dismisses an essentialist concept of actors but also abstains from other reifying constructions, as for instance the conception that actors are something like containers of knowledge and motives. He abandons concepts like "subjective stocks of knowledge" or "shared knowledge" and focuses exclusively on the question of "How?" How is communication achieved? How can members recognize if they have reached a common understanding (for all practical purposes)? How can misunderstandings or diverging perspectives be detected? How is a woman identifiable as a woman, and jurors as jurors? In 1953 Garfinkel introduced the notion of 'ethnomethods' and of 'ethnomethodology,' since then he speaks of 'members methods'. The basic idea is simple and plausible: Everyday life is ordered meaningfully. This order is produced and made intelligible by members. Thus the members must know methods to achieve this (Garfinkel 1974).

Later on, Garfinkel speaks of "embodied practices". By the notion of "practices" he avoids a confusion with action theory that is often associated with "action" and "actors". By "embodied" he points to the bodies involved-which is the result of studying Merleau-Ponty (1962) — but not in the sense of the bodies of "actors" but in the sense of "embodied practices". When observing practices one inevitably observes bodily movements, and the practices in their pursuit constitute the situated identities of involved members. Now and then, the late Garfinkel still spoke of "actors" and "the actor's point of view" but always in this restricted sense. He considers settings as self-organizing and thereby eliminates the nimbus of an agens. Here we find another analogy to Luhmann's systems theory as Luhmann also tries to eliminate all the anthropological assumptions and metaphysical premises that are taken as a matter of course in the natural attitude of everyday life und usually remained unquestioned in sociology, too. In Luhmann's theory it is not actors but the communication system that communicates, and if there are "persons" or "actors" it is because the communication system decides to constitute "persons" and "actors" and to attribute "actions" and "behaviors" to them. 
A New Perspective on the Problem of Order

Already in his first text, Seeing sociologically, Garfinkel (2006: 109ff.) considered actors not as concrete entities but as "symbol treaters". And he found in Schutz's ([1945] 1962) concept of cognitive style "a set of conceptions that will specify the conditions of treatment" (109):

...(The) 'cognitive style' has been defined when the empirical specifications of the following concepts have been provided: (1) epoché; (2) a specific form of sociality; (3) a specific mode of attention to life; (4) a specific form of spontaneity; (5) a specific mode of time consciousness; and (6) a specific way of experiencing the self. There are at least six features of cognitive style. Further experience may reveal more (Garfinkel 2006: 110).

Schutz used these criteria in order to characterize and discern multiple realities, like the world of everyday life, the worlds of imageries and phantasms, the world of dreams or the world of science. Garfinkel suggests using them to describe empirical social settings and exemplifies this by pondering on which cognitive style a guard of the university library has. He considers the structure of the library "as a system of coordinated actions" (110) in which a class of social persons is responsible to prevent theft. He asks a set of hypothetical questions to the guard and demonstrates by hypothetical answers that Schutz's criteria are quite illuminating for describing which cognitive style a guard operates with. At the same time it becomes evident that proper methods for an empirical investigation of such issues await development.

Following Parsons (and Hobbes), Garfinkel accepts the problem of social order as the key question of sociology. In Seeing sociologically he already states that Parsons had been radical about the problem but not radical enough in his theoretical analyses (2006: 137). In particular he failed to challenge some very important naturalistic constructions. The invariant structures that Husserl's phenomenology described were in this respect quite different from the theoretical framework that Parsons proposed in The Structure of Social Action ([1937] 1968). The latter was applicable, as Schutz had shown, to teleological action but not to expressive, for instance intimate activities. In his dissertation of 600 pages, The perception of the other, Garfinkel (1952: 90-150) compares the constitutive premises of Parsons' approach with those of Schutz's life-world analysis and treats them as two alternative paradigms for explaining social order: the "correspondence theory" and the "congruence theory," both of which he characterizes and compares along six criteria. Although a doctoral student of Parsons, Garfinkel favored the congruence theory of Schutz and designed and carried out his first incongruity experiment (391-602). His basic idea was this: If a social situation is considered as a meaningful order of objects, it represents a finite province of meaning that is based on the operation of a certain cognitive style that is shared among the members. Breaching one of these constitutive assumptions should - this was the hypothesiscause trouble and produce disorder.

The correspondence between Schutz and Garfinkel (Psathas 2009) reveals that Schutz doubted if there are such fundamental differences between the theoretical decisions of Parsons and those of himself. And he was uncertain if he had really 
understood what Garfinkel meant by "correspondence theory" or "congruence theory" and if they have such different implications for empirical research. Indeed, in his correspondence with Parsons, Schutz had argued that the phenomenological analysis of the 'subjective perspective' would serve as a frame of reference for Parsons' sociological theory and that Parsons would not need to modify his approach. The phenomenologically explicated structures of the life-world would rather make evident which meaning transformations sociological theories produce when translating the subjective sense of actions in everyday life into scientific models of homunculi (Schutz and Parsons 1978).

\section{Developing Adequate Sociological Descriptions}

The major goal of Schutz's life-world analysis was to provide a proper philosophical foundation to the methodology of the social sciences. In contrast to the natural sciences, the methodology of the social sciences requires a constitution theory of the social world. Based on his analyses, Schutz formulated a number of methodological postulates the most important of which are the postulate of subjective interpretation and the postulate of adequacy. Schutz (1962: 24ff.) demonstrates that the "postulate of the subjective interpretation of meaning" originates in everyday life and is a principle of constructing course-of-action types in common-sense experience. A social science that intends to describe and explain social reality also has to adopt this principle. It requires that generalizations and idealizations on a high level of abstraction are accepted only as a kind of shorthand and must be transformable to the subjective sense of human action. The postulate of adequacy requires that the secondorder constructs of the social scientist are consistent with the first-order constructs of common-sense experience of the social reality. This implies that each term of a scientific model of human action must be comprehensible to the actor in question as well as to his co-actors on a common-sense level (40). Schutz considered it as the most important task of an action theory analyzing the method of typification in its details. Social scientists must attend carefully to each subtle change of meaning that results from a modification of the system of relevances or of a transformation from abstract to concrete notions and from anonymous to personal ideal-types. And Schutz points out that there always remains an insurmountable difference (or gap) between the homunculi of a social scientific model and the common-sense experience of actors in everyday life, because the ideal-typical constructions can never capture those aspects that transcend the type.

On the one hand, these postulates are quite challenging as a great number of social scientific theories do not comply with them. On the other hand, they are not concise enough to solve disputes between diverse action theories. While Schutz explained the postulate of subjective interpretation quite extensively, his definition of the postulate of adequacy remained rather vague. He also changed its formulation several times without making it much clearer over the course of time. As a methodologist, he regarded himself as scholar of the scientists and not its tutors. He spent quite some reflection on a descriptive analysis of economics (cf. Eberle 1988, 2009) which formed the context of his academic socialization in Vienna. As I have argued elsewhere (Eberle 2010), Schutz presumably did not wish to publicly 
criticize his friends from Austrian Economics and the Mises-Circle. In his personal correspondence, however, he did. I have therefore suggested formulating the postulate much more restrictively: Adequacy requires capturing the actors's subjective sense (meaning) empirically (which restricts rational choice models to quite a narrow realm of human action).

Garfinkel was more rebellious than Schutz. His conception of adequacy is much more radical and restrictive than the version of Schutz. In addition, he was not interested in the adequacy of scientific homunculi constructions but in the adequacy of empirical descriptions. An adequate description in Garfinkel's sense requires that the observable practices in a setting are described in all their details and thereby explicate how social order is produced, made accountable and intelligible. Garfinkel actually implements the famous dictum of phenomenology: "Back to the phenomena!" Ethnomethodology analyzes what is empirically observable, discernable and intelligible. It attends to the details that are usually overlooked by other social scientists, and investigates how they are constitutive of the ongoing event. With this focus on the actor's perspective and the details of social action, Garfinkel challenged the prevailing criteria for adequate research. As Rawls (2002: 51ff.) has argued, he directly contradicted "the faith in formalism, technical reason, and mathematicized representations of social behavior that came do define postwar sociology" (52), and he also avoided "the fallacy of misplaced abstraction" in which interpretive sociologists and pragmatists had engaged (51). Garfinkel was critical towards the general and abstract concepts of Parsons' structural functionalism, but also of poststructuralism and postmodernism- "the details of social order should be empirically observable without conceptual or theoretical mediation" (52). The concepts of sociological theories are only "glosses," they rather obscure than clarify social reality.

Grounded on this perspective, Garfinkel developed an empirical research program that is characterized by openness, intellectual curiosity and a willingness to experiment. He used interviews, observations, field reports from his students, a variety of breaching experiments as well as audio- and video-taped materials for ethnomethodological analysis. And these analyses consisted in highly complex, elaborated and detailed reflections that were formulated in a difficult language and therefore remained incomprehensible to many readers. If Garfinkel really succeeded in clarifying social reality or if he rather obscured it himself, is a matter of debate. In any case, all those of his students who attempted to explain what Garfinkel "really" thought and how he could be "properly" understood (as, for instance, Leiter 1980; Handel 1982; Heritage 1984; Livingstone 1987; Lynch and Sharrock 2011; in Germany: Bergmann 1987/1988, 2000a, b), were a great help to others to whom Garfinkel's writings remained rather inaccessible. Recently, Rawls (2002, 2006, 2008) - although not a direct student of Garfinkel but a scholar with close contact to him-has provided many illuminating comments and explanations in her introductions to Garfinkel's texts that she recently published (Garfinkel 2002, 2006, 2008). Internal debates among ethnomethodologists, however, show that there is no broad consensus about the "proper" interpretation. And insiders know that Garfinkel himself was not very helpful in clarifying things. His focus was on doing ethnomethodology, not on talking about it. 
Since the 1970s more and more ethnomethodologists converted to conversation analysis as CA seemed to produce "better," i.e., more demonstrable and plausible results. This reduced the scope of research interest but strengthened the methodical rigor: Interview data or field notes is not accepted as proper data anymore, only audio- and video-taped material are used for analysis. This allows for attending to detail in ways no other procedure does; each sequence of interaction can be repeated a hundred times until everything has been analyzed in every detail. Ethnomethodology and conversation analysis have much enriched qualitative methods and qualitative research, especially with its research attitude that no proposition is accepted if it cannot be substantiated in the data at hand. And the rigorous stance that all relevant context is to be produced within the setting prohibited an observer or analyst to introduce contextual knowledge from the outside: either it is observably made relevant within the setting or it is of no importance for the analysis either. This methodical principle helped, as in hermeneutics, to discern very carefully which knowledge was of use in the observed setting and what could not be seen properly in the data.

While many ethnomethodologists had become conversation analysts, Garfinkel developed the studies of work (Garfinkel 1986). In this context he developed the concept of "unique adequacy": ethnomethodologists should be competent practitioners of the subject they study. If you investigate ordinary conversations you may assume that any ordinary member of that collectivity is a competent practitioner. If you research a setting with a particular population, however, like a science laboratory or the work of a special profession, it is difficult to make proper sense of what is going on if you are not a competent member of that setting. Garfinkel therefore required that his students became competent practitioners of the work they studied; that they become mathematicians in order to pursue the work of mathematicians; that they become lawyers in order to study the work of lawyers, and so on. If you want to understand the details of the local order production, an ethnomethodologist must not only be acquainted with the field but be a competent practitioner of that type of work setting him- or herself. In his recent publication Garfinkel (2002) even moved a step further by not tying "adequacy" to descriptions but to (successful) instructions.

\section{Phenomenology and Ethnomethodology: A Reconsideration}

\section{Protosociology, Philosophical Anthropology and Phenomenological Sociology}

Let us sum up some major aspects. In German sociology, the results of Schutz's lifeworld analysis are seen as a whole. The analysis of the structures of the life-world (Schutz and Luckmann 1973, 1989) represent, as Schutz had intended, a philosophical foundation of the social sciences. Luckmann calls them a protosociology that functions as a mathesis universalis, serves as a tertium compartionis and allows for solving the problem of measurement in the social sciences. He makes a sharp distinction between protosociology and sociology on methodological grounds: The life-world analysis proceeds phenomenologically, sociology 
scientifically. Phenomenology is a philosophy that aims at describing the universal structures of subjective orientation in the life-world. It analyzes phenomena of subjective consciousness in an egological perspective by means of a reflexive method. Sociology is a science that aims at explaining the general properties of the objective world. It analyzes phenomena of the social world in a cosmological perspective by means of an inductive method. Therefore, there is no such thing like a 'phenomenological sociology' but of course, protosociology and sociology should be related. Berger and Luckmann (1966) designed such a relationship in The social construction of reality, a phenomenologically based sociology of knowledge. Luckmann (2007: 127-137) consequently distinguished between the subjective constitution in subjective consciousness and the social construction in society.

While Luckmann emphasized the phenomenological aspect of Schutz's lifeworld analysis, Srubar elaborated the-hitherto rather overlooked-pragmatic aspect. He showed that Schutz developed two poles of the life-world: the subjective pole and the pragmatic, social pole. The life-world is not only constituted in subjective consciousness - the subjective pole-but also in social reality: actors produce through their operations and interactions a material, cultural world. The pragma is, in other words, not just the subject of sociology but also-on a fundamental level-of the life-world analysis. Srubar does not call this a protosociology but a philosophical anthropology, as Schutz did following Scheler. Nevertheless, he agrees with Luckmann with regard to its basic function: it serves as a tertium comparationis that provides a proper basis for the methodology of the social sciences. In contrast to the natural sciences, the methodology of the social sciences does not only have one but two pillars: It does not suffice to ponder on the rationality of constructing scientific hypotheses and models; the methodology of the social sciences in addition requires a constitution theory of the meaningful structures of the social world (Eberle and Srubar 2010; Schütz 2010). As a tertium comparationis it also allows for cultural comparisons in a new way.

These two variants, the phenomenological protosociology and the pragmatic constitution theory, are the prevailing interpretations of Schutz's life-world analysis in German sociology. Despite their differences, they have much in common: Both consider the results of Schutz's life-world analysis as a whole and as a proper foundation of the methodology of the social sciences. A third one, the social phenomenology as conceived by Richard Grathoff (1989), remained much less influential. Grathoff feared that Schutz's structures of the life-world had become reified and called for concrete phenomenological studies of social milieus. The picture has nowadays multiplied in manifold ways, as a recent book on Phenomenology and Sociology (Raab et al. 2008) demonstrates, but the basic lines as outlined above are still clearly visible.

In the United States, Schutz's life-world analysis was received differently. It was of interest to phenomenological philosophers, on the one hand, and to sociologists on the other. George Psathas (2004) wrote a detailed account of Alfred Schutz's influence on American sociologists and sociology. He states that this influence did not occur during Schutz's lifetime but after his death, and focuses on three outstanding sociologists to describe it: Schutz's students Helmut Wagner and Peter 
L. Berger, and Harold Garfinkel who was not his student but who was, as we have seen, clearly influenced by Schutz.

Wagner became a Schutzian social scientist, expositor of Schutz's ideas and later a biographer of Schutz; Peter Berger was one of the first to introduce a broad based phenomenological perspective to a generation of sociologists. Then, with Thomas Luckmann, Schutz's concepts and theories were introduced by incorporating them in their formulation of what became an influential version of the sociology of knowledge. Harold Garfinkel's development of ethnomethodology owes its origins to Schutz's remarkable insights into the world of everyday life, common sense knowledge, and the taken-for-granted (Psathas 2004: 9).

Berger basically agreed with Luckmann's position but did not push the idea of a phenomenological protosociology any further. Although Berger and Luckmann's Social construction of reality was quite influential in North American sociology, too, there were obviously not many sociologists who interpreted the life-world analysis as a protosociology that would found the methodology of sociology. Many did presumably not even realize the clear distinction between phenomenology and sociology upon which the structure of the book was built; most perceived it rather as an alternative sociological approach. This is undoubtedly due to the strong influence of Garfinkel. Most of Garfinkel's students perceived Schutz as precursor of ethnomethodology and many abandoned talking of phenomenology per se. A number of sociologists, however, adhered to phenomenology and disseminated the label 'phenomenological sociology'.

The most famous among the proponents of a phenomenological sociology was George Psathas $(1973,1989)$. He was modest enough not to mention himself as one of those American sociologists who was strongly influenced by Schutz (Psathas 2004). Psathas remained one of the few who kept close ties to phenomenology while also maintaining ties to ethnomethodology and conversation analysis, which is manifested by his committed involvement in the Society for Phenomenology and Existential Philosophy as well as in the International Institute of Ethnomethodology and Conversation Analysis. It may have been through the influence of Herbert Spiegelberg (1982), whose seminars at Washington University in St. Louis he attended, that Psathas saw phenomenology as a broad movement rather than a single strand. In this vein, Psathas kept an integrative position or, as Bird (2009) calls it, an assimilative approach. In contrast to all the common practices of demarcation and exclusion, he emphasized the commonalities without disregarding the differences (cf. Eberle 2012).

Phenomenological sociologists sought to find a "synthesis" between phenomenology and sociology (Waksler 1969). Psathas designates phenomenology "as philosophy, method, and approach for social science" and Alfred Schutz is said to provide "a direct entry into phenomenological sociology" (Psathas 1973: 7). He considered phenomenological sociology as a new paradigm that offers an alternative to the restricted potential of positivist perspectives - at the time behaviorism and structural functionalism. For Psathas (1973, 1989), phenomenological sociology offers a fresh, open, and innovative approach that encourages suspension of the 
natural attitude, seeing the phenomena-as-they-are, and avoiding preconceived sociological notions and concepts as well as the established recipes and formulas of research procedure. In Psathas' interpretation, “questions about how the life-world is possible, how one can know another's mind, whether society is objectively real, and so forth," must be tackled by philosophy. Studying "the life-world as it is experienced by ordinary human beings living in it" and "to discover what they are experiencing, how they interpret their experiences, and how they themselves structure the social world in which they live" are, however, tasks of phenomenological sociology (1973: 15f.).

\section{Is Ethnomethodology a Phenomenological Sociology?}

Psathas (1989: 79-98) explicitly calls ethnomethodology a phenomenological approach in the social sciences and carefully discusses the differences and commonalities between Schutz's phenomenology, ethnomethodology, and other versions of a sociology of knowledge (Psathas 1989, 2004, 2009). Garfinkel acknowledged that he was extensively influenced and inspired by phenomenologists, in particular by Schutz, later by Merleau-Ponty, but he has never labeled his approach a 'phenomenological sociology'. He created the new term 'ethnomethodology' and launched it from the outset as a novel sociological approach to the problem of social order. Furthermore, he practiced and recommended the method of "misreading" - scholarly faithfulness has never been a priority of ethnomethodology, it was considered appropriate to raid other scholars for ideas that might be useful to empirical inquiry (see Lynch 2004 and Sharrock 2004 in their discussion with Dennis 2004). By "misreading"-which was often misunderstood-Garfinkel did not mean "reading incorrectly" but "reading alternately" (2002: 112, n36).

Is Garfinkel's ethnomethodology a phenomenological sociology? Yes and no. Let us go back to Husserl's ego-cogito-cogitatum. As Srubar has argued, the life-world has a subjective and a pragmatic, social pole. The life-world is therefore not only perceived and experienced in subjective consciousness; it is also constituted by pragmatic social actions. Social phenomena always have noetic as well as noematic aspects. While the question "What can I know?" makes us consider the noesis, the question "Why do we see something as something?" leads to the noema, to the meaningful actions that constitute the social world. Garfinkel's question "What makes jurors 'jurors'?" is therefore a genuine phenomenological question that focuses on the noema. While Schutz primarily analyzed more the noetic aspect, the mode of givenness of social phenoma, Garfinkel is more interested in the noema of social phenomena. Both Schutz and Garfinkel were, however, aware that the noema of pragmatic, social phenomena is constituted by communicative efforts. Garfinkel's Agnes was recognizable as a woman because she made herself accountable as a woman. Insofar as ethnomethodology pursues constitutive analyses of social phenomena it may be properly called, in Psathas' broad meaning of the term, a phenomenological approach in sociology.

On the other hand, classic phenomenological analysis starts with the subjective experiences of the ego, not with those of the alter ego. Some phenomenologistseven phenomenological sociologists-are interested in exploring the experiences of 
participants of concrete social settings before they were transformed into text. Subjective experiences, nota bene, that are not observable by observers; the researcher must therefore participate and phenomenologically analyze his own, personal experiences (Hitzler and Eberle 2004). Ethnomethodology restricts its empirical inquiry to the pragmatic, social pole of the life-world and does not extend it to the subjective pole. It is, in Srubar's terminology, only interested in the pragma of the life-world and not in the intentional acts of subjective consciousness. The actor's point of view is analyzed only insofar as it is empirically observable; all the rest of his or her subjectivity is lost. Of course, to take into account other aspects of the actor's subjective experiences would imply to extend the type of accepted data to talk, interview or narration.

It is certainly legitimate - as it is for any other sociological approach - that ethnomethodology explicitly restricts its focus of inquiry and also accepts only certain kinds of data, as video-recorded data. As already stated above, ethnomethodology (and conversation analysis) have contributed much to the quality of qualitative research. As Schutz's life-world analysis is broader in scope, it allowsas a tertium comparationis - to clarify a little bit the scope of ethnomethodology. All of Schutz's insights that he gained by the phenomenological analysis of the modes of givenness in the subjective consciousness remain beyond the scope of ethnomethodology if they are not observable by an alter ego: the petites perceptions, dreams and fantasies, memories and anticipations of an actor, religious and mystic experiences, and so on. Schutz's life-world analysis elucidates how much of an actor's subjective experience is missing. In addition, it clearly describes the fundamental differences of analyzing one's own experiences and analyzing the meanings another actor displays. Ethnomethodology can, of course, counter that all these subjective experiences are dispensable for explaining social order; that they are only relevant insofar as they are accountable and observable in a social setting.

Although this assumption helps to discipline empirical analyses methodically, it is only partially plausible. The practice of interpreting recorded material makes evident that it is often difficult to discern what actors actually orient themselves to. In workplace studies, for instance, there are practices that you can recognize by observation; others, however, remain indeterminable. You can follow a person's gaze but cannot figure out what the person really looks at, and of course, you cannot find out what the person actually sees when looking at something. Is that irrelevant because it was not sequentially implicative? Maybe it is sequentially implicative later on, and the researcher does not realize it? Why not talk to the actor and listen what he or her has to tell about his or her orientation? Why not use his or her subjective experience as a resource for further analysis?

Knorr Cetina and Bruegger (2002) researched currency traders at work. The traders sat in front of many monitors scanning them constantly. As the observers often could not recognize what they were looking at, and even less what they were seeing, they asked them: What are you looking at, what are you seeing, what does that mean for your on-going work? This simple procedure proved very helpful, although it was a little intrusive as the dealers had to tell things they usually do not tell while working. But the observers this way understood much more of what was going on than by pure observation. Garfinkel's unique adequacy criterion was taken 
care of, as Bruegger had worked as a currency trader on the same trading floor for 4 years and was a skilled practitioner in the field. Nevertheless, he reported ${ }^{3}$ that sometimes he could not make sense of an action that he observed; when asking that trader what he was doing and why, the trader resisted to explain and said: you know that yourself! The observed trader assumed that what he was doing was common practice and would be intersubjectively intelligible to members, but in fact it was not. This instance shows that Garfinkels "unique adequacy criterion" requires stretching in the direction of Schutz's postulate of adequacy: Intersubjectivity or reciprocity of perspectives, as Schutz called it, may be given if something is common routine. Actions that are beyond routine, however, cannot be understood as easily by a peer, not even by a competent practitioner in the field. The unique adequacy criterion assumes that practitioners know, but it must be ultimately radicalized and understood as adequacy in Schutz's sense: grasping the subjective sense of an action adequately.

To sum up: Human beings experience their life-world at its subjective pole as well as its pragmatic, social pole. Much of what they experience is not "real" in the sense of the paramount reality of everyday life, but only dreamed or imagined and fantasized about. And only part of the subjective experiences in everyday life concern the social world. Schutz's life-world analysis spans the whole spectrum. Goffman, like Garfinkel, studied the interaction order and was as broad as Schutz in his theoretical scope: In his Frame Analysis (1974) he studied the organization of experience in its social as well as subjective aspects. ${ }^{4}$ Ethnomethodology restricts its focus to social phenomena, i.e., to the pragmatic pole of the life-world and to observable, recordable data only. But the field of ethnomethodology has meanwhile diversified, too. More and more ethnomethodologists are opening up to ethnographic procedures and are taking other sorts of data into account, too. And many integrative concepts of Goffman as well. Phenomenological sociologists, in Psathas' broad interpretation, have remained open to the subjective pole of the life-world all along, aiming at discovering what actor's are experiencing, how they interpret their experiences and how they structure the social world they live in. Phenomenological sociologists may reflect moreover, as also Psathas (1973) has argued, on their own subjective experiences in order to gain insights into the dynamics of the social world. ${ }^{5}$

\section{Life-World Analysis as Protosociological Foundation: An Obsolete Project?}

Husserl ([1936]1970) hoped to solve The crisis of European sciences by a transcendental analysis of the life-world. Schutz intended to provide the social sciences with a proper philosophical foundation through a phenomenological lifeworld analysis. In Luckmann's view, Schutz's structures of the life-world are such a protosociology, a mathesis universalis and tertium comparationis for the social sciences. This project can be elaborated and refined, but it remains a project of

\footnotetext{
3 Personal communication (Brugger pursued this research at our institute).

${ }^{4}$ For a comparison of Schutz and Goffman see Eberle (1991).

5 For recent versions of a phenomenological sociology, see Bird (2009) or Nasu (2012).
} 
establishing a foundation for the methodology of the social sciences. However, has this project not become obsolete at the beginning of the $21^{\text {st }}$ century? Who, after the wave of postmodernism, still believes in a "proper," even "apodictic" (Husserl), philosophical foundation of the social sciences? Hermeneutic philosophy (Bollnow 1970) has asserted for several decades already that there is no archimedic point of cognition and no stable foundation for any kind of reflection.

Luckmann acknowledges the problem of epistemological reflexivity: Phenomenological analysis cannot avoid using language for its descriptions and cannot strip itself completely from a specific colloquial language. Even if the method of phenomenological reduction allows the systematic stripping of cognition from the historically and culturally specific elements, how can we be sure that we have reached that plane of universal and invariant insights? To solve this problem, Knoblauch suggests - in line with Luckmann - a triangulation of three different methods: the phenomenological method is "to be corrected and complemented by two other methods: (a) the 'cosmological' methods of the sciences studying the human body, on the one hand, and (b) the sciences studying the variety of human culture and social structure, on the other" (Knoblauch 2011: 140f.). If such a triangulation is accepted, Luckmann's dualistic methodological distinction between phenomenology and science still holds, but the sciences then are included in the foundational project, at least for correction and complementarity. Dreher furthermore reports that Luckmann called for a "parallel action" of phenomenological and social scientific research (2007: 9f., 2009).

In conclusion, nobody nowadays assumes that the phenomenological or the pragmatic life-world analysis by Schutz (or others) provide an "apodictic" foundation of the methodology of the social sciences. But there is no alternative in sight that is so broad in scope and so rich in detail. Schutz's life-world analysis hitherto provides the best constitution theory of the meaningful structures of the social world-which is the second, and crucial pillar of the methodology of the social sciences. It must not be reified but represents an apt framework to scrutinize methodological questions of sociology.

\section{Ethnomethodology as a Sociologia Perennis?}

Garfinkel did not perceive Schutz's life-world analysis as a whole but used single essays for inspiration in order to find a novel sociological approach. He set out to pursue constitutive analyses of social phenomena as an empirical, sociological enterprise. He reduced his focus to the pragmatic, social pole of the life-world and restarted analysis anew. By attending to the "haecceities," to the contingencies and to the subtle details of concrete social situations, he fulfilled the original dictum of phenomenology: Back to the phenomena! Garfinkel proved to be very creative and innovative, and he inspired more than one generation of ethnomethodologists and many sociologists beyond. He enriched sociology greatly by a new perspective and contributed to qualitative research by novel methodological premises and new methodical procedures. However, while Husserl and Schutz strived for a philosophia perennis, i.e., for universal philosophical insights that are independent of a specific epoch or culture, the status of Garfinkel's constitutive rules, ethnomethods, 
or practices have remained obscure. Did he strive for a sociologia perennis? And where did he end up?

The goals of Husserl's and of Schutz's life-world analyses were clear: to describe the universal and invariant structures of the life-world. Schutz's phenomenological and pragmatic analyses intended to gain insights that apply to the conditio humana per se-that means they are formulated on an adequately abstract and general level. Garfinkel resisted to specify how general and abstract ethnomethods should be described. How many of the elucidated practices extend over several settings, and how many are specific to the concrete setting under investigation? This remained vastly unclear, and one sometimes gets the impression that ethnomethodologists employ the same "theoretical" concepts and the same methods of analysis, but it does not become manifest if their empirical insights refer only to that specific research setting or if they are meant to be more general. It is certainly an illusion to purport the principle of data-guidedness, refuse theoretical considerations and hope that further research will provide more clarity. In my opinion, it is high time to attempt giving an overview over the crucial empirical insights that ethnomethodological studies have provided so far. After half a century of ethnomethodological research, such an inventory as well as a theoretical assessment of the findings ought to be feasible. Schutz's life-world analysis could serve as a frame of reference for such an endeavor. 6

\section{References}

Berger, P. L. (1963). Invitation to sociology. A humanistic sociology. Garden City, NY: Doubleday.

Berger, P. L. (1966). On existential phenomenology (II). American Sociological Review, 31, $259-260$.

Berger, P. L., \& Luckmann, T. (1966). The social construction of reality. A treatise in the sociology of knowledge. Garden City, NY: Doubleday.

Bergmann, J. (1987/1988). Ethnomethodologie und Konversationsanalyse. (Studienbrief mit 3 Kurseinheiten), FernUniversität GHS Hagen, Hagen.

Bergmann, J. (2000a). Harold Garfinkel und Harvey Sacks. In U.v. Flick, E. Kardorff, \& I. Steinke (Eds.), Qualitative Sozialforschung. Ein Handbuch (pp. 51-62). Reinbek: Rowohlt.

Bergmann, J. (2000b). Ethnomethodologie. In U.v. Flick, E. Kardorff, \& I. Steinke (Eds.), Qualitative Sozialforschung. Ein Handbuch (pp. 118-135). Reinbek: Rowohlt.

Bird, G. (2009). What is phenomenological sociology again? Human Studies, 32, 419-439.

Bollnow, O. F. (1970). Philosophie der Erkenntnis. Das Vorverständnis und die Erfahrung des Neuen. Stuttgart, Berlin, Köln, Mainz: W. Kohlhammer.

Carnap, R. ([1928]1967). The logical structure of the world: Pseudoproblems in philosophy, Berkeley, CA: University of California Press.

Coulter, J. (1979). The social construction of mind. Studies in ethnomethodology and linguistic philosophy. London: Macmillan.

Dennis, A. (2004). Lynch on Schutz and science: Postanalytic ethnomethodology reconsidered. In Theory \& Science, Vol. 5.1. (found on March 1, 2012 at) http://theoryandscience.icaap.org/content/ vol5.1/dennis.html.

\footnotetext{
${ }^{6}$ I am, of course, aware that many ethnomethodologists would prefer a Wittgensteinian framework to a phenomenological one, beginning with Jeff Coulter (1979) and ending with all those who presently advocate the "practice turn" (cf. Woermann 2011). For an ethnomethodological view of epistemology cf. Sharrock and Anderson (1989).
} 
Dreher, J. (2007). Einleitung. In T. Luckmann (Ed.), Lebenswelt, Identität und Gesellschaft. Schriften zur Wissens- und Protosoziologie (pp. 7-23). Ed. by Jochen Dreher. Konstanz: UVK.

Dreher, J. (2009). Phenomenology of friendship. Construction and constitution of an existential social relationship. Human Studies, 32(4), 401-417.

Eberle, T. S. (1984). Sinnkonstitution in Alltag und Wissenschaft. Der Beitrag der Phänomenologie an die Methodologie der Sozialwissenschaften. Bern/Stuttgart: Paul Haupt.

Eberle, T. S. (1988). Die deskriptive Analyse der Oekonomie durch Alfred Schütz. In E. List \& I. Srubar (Eds.), Alfred Schütz. Neue Beiträge zur Rezeption seines Werkes (pp. 69-119). Studien zur Oesterreichischen Philosophie. Ed. by R. Haller, Band XII, Amsterdam: Rodopi.

Eberle, T. S. (1991). Rahmenanalyse und Lebensweltanalyse. In R. Hettlage \& K. Lenz (Eds.), Erving Goffman-ein soziologischer Klassiker der zweiten Generation (pp. 157-210). Bern/Stuttgart: Paul Haupt.

Eberle, T. S. (2000). Lebensweltanalyse und Handlungstheorie. Beiträge zur Verstehenden Soziologie. Konstanz: UVK.

Eberle, T. S. (2008). Phänomenologie und Ethnomethodologie. In J. Raab, M. Pfadenhauer, P. Stegmeier, J. Dreher, \& B. Schnettler (Eds.), Phänomenologie und Soziologie (pp. 151-161). Wiesbaden: VSVerlag für Sozialwissenschaften.

Eberle, T. S. (2009). In search of aprioris: Schutz's life-world analysis and Mises's praxeology. In H. Nasu, L. Embree, G. Psathas, \& I. Srubar (Eds.), Alfred Schutz and his intellectual partners (pp. 493-518). Konstanz: UVK.

Eberle, T. S. (2010). Phenomenological life-world analysis and the methodology of social science. Human Studies, 33(2-3), 123-139.

Eberle, T. S. (2012). Phenomenology and sociology: Divergent interpretations of a complex relationship. In H. Nasu \& F. C. Waksler (Eds.), Interaction and everyday life: Phenomenological and ethnomethodological essays in honor of George Psathas (pp. 151-167). Lanham: Lexington Books.

Eberle, T. S., \& Srubar, I. (2010). Einleitung. In A. Schütz (Ed.), Zur Methodologie der Sozialwissenschaften (pp. 9-44). ASW Vol. IV, Ed. by T. S. Eberle, J. Dreher und G. Sebald. Konstanz: UVK.

Endress, M. (2008). Reflexive Wissenssoziologie als Sozialtheorie und Gesellschaftsanalyse. Zur phänomenologisch fundierten Analytik von Vergesellschaftungsprozessen. In J. Raab, M. Pfadenhauer, P. Stegmeier, J. Dreher, \& B. Schnettler (Eds.), Phänomenologie und Soziologie (pp. 85-95). Wiesbaden: VS-Verlag für Sozialwissenschaften.

Garfinkel, H. ([1948]2006). Seeing sociologically. The routine grounds of social action. Lanham: Rowman \& Littlefield.

Garfinkel, H. (1952). The perception of the other. Unpublished dissertation, Harvard University.

Garfinkel, H. (1963). A conception of, and experiments with, 'trust' as a condition of stable concerted action. In O. J. Harvey (Ed.), Motivation and social interaction (pp. 187-238). New York: Ronald Press.

Garfinkel, H. (1967). Studies in ethnomethodology. Englewood Cliffs, NJ: Prentice-Hall.

Garfinkel, H. (1974). The origins of the term 'ethnomethodology'. In R. Turner (Ed.), Ethnomethodology. Selected readings (pp. 15-18). London: Penguin.

Garfinkel, H. (1986). Ethnomethodological studies of work. London/New York: Routledge \& Kegan Paul.

Garfinkel, H. (2002). Ethnomethodology's program. Working out Durkheim's aphorism. Lanham: Rowman \& Littlefield.

Garfinkel, H. (2008). Toward a sociological theory of information. Boulder/London: Paradigm Publ.

Grathoff, R. (1989). Milieu und Lebenswelt: Einführung in die phänomenologische Soziologie und die sozialphänomenologische Forschung. Frankfurt am Main: Suhrkamp.

Handel, W. (1982). Ethnomethodology. How people make sense. Englewood Cliffs, NJ: Prentice-Hall.

Heritage, J. (1984). Garfinkel and ethnomethodology. Cambridge: Polity Press.

Hitzler, R., \& Eberle, T. S. (2004). Phenomenological lifeworld analysis. In U. Flick, E. v. Kardorff \& I. Steinke (Eds.), A companion to qualitative research (pp. 57-72, B. Jenner, Trans.). London: Sage.

Hofstede, G. (1997). Cultures and organizations: Software of the mind. London: Mc Graw Hill.

Husserl, E. ([1936]1970). The crisis of European sciences and transcendental phenomenology. Evanston: Northwestern University Press.

Knoblauch, H. (2011). Relativism, meaning and the new sociology of knowledge. In R. Schantz \& M. Seidel (Eds.), The problem of relativism in the sociology of (scientific) knowledge (pp. 131-156). Frankfurt, Paris, Lancaster: Ontos.

Knorr Cetina, K., \& Bruegger, U. (2002). Global microstructures: The virtual societies of financial markets. American Journal of Sociology, 107(4), 905-955. 
Leiter, K. (1980). A primer to ethnomethodology. New York: Oxford University Press.

Livingstone, E. (1987). Making sense of ethnomethodology. London/New York: Routledge \& Kegan Paul.

Luckmann, T. (1973). Philosophy, science, and everyday life. In M. Natanson (Ed.), Phenomenology and the social sciences (pp. 145-185). Evanston: Northwestern University Press.

Luckmann, T. (1979). Phänomenologie und Soziologie. In W. M. Sprondel \& R. Grathoff (Eds.), Alfred Schütz und die Idee des Alltags in den Sozialwissenschaften (pp. 196-206). Stuttgart: Ferdinand Enke.

Luckmann, T. (2007). Lebenswelt, Identität und Gesellschaft. Schriften zur Wissens- und Protosoziologie. Ed. by Jochen Dreher. Konstanz: UVK.

Luhmann, N. ([1984]1995). Social systems. Translated by John Bednarz, Jr., with Dirk Baecker; foreword by Eva M. Knodt. Stanford, California: Stanford University Press. [German original: Soziale Systeme: Grundriss einer allgemeinen Theorie. Frankfurt am Main: Suhrkamp 1984.].

Lynch, M. (1993). Scientific practice and ordinary action. Cambridge: University Press.

Lynch, M. (2004). Misreading Schutz: A response to Dennis on 'Lynch on Schutz on science'. In Theory \& Science, Vol. 5.1. (found on March 1, 2012 at) http://theoryandscience.icaap.org/content/vol5.1/ lynch.html.

Lynch, M., \& Sharrock, W. (2011). Ethnomethodology. Four-Volume-Set. London: Sage.

Merleau-Ponty, M. (1962). Phenomenology of perception. English translation by Colin Smith. London: Routledge and Kegan Paul.

Nasu, H. (2012). Alfred Schutz and sociology: Is a phenomenological sociology possible and required today? Quaderni di Teoria Sociale, N. 12, Special Issue: Sulla rilevanza della sociologia fenomenologica. Dibattito su Alfred Schutz, edited by L. Muzzetto (forthcoming).

Parsons, T. ([1937]1968). The structure of social action. Vol. I: Marshall, Pareto, Durkheim; Vol. II: Weber, New York: The Free Press.

Parsons, T. (1966). Societies: Evolutionary and comparative perspectives. Englewood Cliffs, NJ: Prentice-Hall.

Pfadenhauer, M. (2010). Peter L. Berger. Reihe 'Klassiker der Wissenssoziologie'. Konstanz: UVK.

Psathas, G. (Ed.). (1973). Phenomenological sociology. Issues and applications. New York: Wiley.

Psathas, G. (1989). Phenomenology and sociology. Theory and research. Boston: The Center for Advanced Research in Phenomenology, University Press of America.

Psathas, G. (2004). Alfred Schutz's influence on American sociologists and sociology. Human Studies, $27,1-15$.

Psathas, G. (2009). The correspondence of Alfred Schutz and Harold Garfinkel: What was the "terra incognita" and the "treasure island"? In H. Nasu, L. Embree, G. Psathas, \& I. Srubar (Eds.), Alfred Schutz and his intellectual partners (pp. 401-433). Konstanz: UVK.

Raab, J., Pfadenhauer, M., Stegmeier, P., Dreher, J., \& Schnettler, B. (Eds.). (2008). Phänomenologie und Soziologie. Wiesbaden: VS-Verlag für Sozialwissenschaften.

Rawls, A. W. (2002). Editors' introduction. In H. E. Garfinkel (Ed.), thnomethodology's program. Working out Durkheim's aphorism (pp. 1-64). Lanham: Rowman \& Littlefield.

Rawls, A. W. (2006). Respecifying the study of social order-Garfinkel's transition from theoretical conceptualization to practices in details. In H. Garfinkel (Ed.), Seeing sociologically. The routine grounds of social action (pp. 1-97). Lanham: Rowman \& Littlefield.

Rawls, A. W. (2008). Editor's introduction. In H. Garfinkel (Ed.), Toward a sociological theory of information (pp. 1-100). Boulder/London: Paradigm Publ.

Scheler, M. (1922). Wesen und Formen der Sympathie. 2. Auflage. Bonn, (pp. 244-307); English Translation: The nature of sympathy, New Haven, 1954, (pp. 213-264).

Schutz, A. (1945). On multiple realities. Philosophy and phenomenological research (June): 533-575. (Reprinted in Schutz 1962, CPI, pp. 207-259).

Schutz, A. (1962). Collected papers (Vol. 1). The Hague: Martinus Nijhoff.

Schutz, A. (1967). The phenomenology of the social world. Evanston, IL: North-western University Press.

Schütz, A. (2006). Sinn und Zeit. Frühe Wiener Arbeiten und Entwürfe. ASW Bd. I, Ed. by M. Michailow. Konstanz: UVK.

Schütz, A. (2010). Zur Methodologie der Sozialwissenschaften. ASW Vol. IV, Ed. by T. S. Eberle, J. Dreher und G. Sebald. Konstanz: UVK.

Schutz, A. and Luckmann, T. (1973). The structures of the life-world (Vol. I, R. Zaner \& H. Engelhardt, Trans.). Evanston, IL: North-western University Press. 
Schutz, A. and Luckmann, T. (1989). The structures of the life-world. (Vol. II, R. Zaner \& D. J. Parent, Trans.). Evanston, IL: North-western University Press.

Schutz, A., \& Parsons, T. (1978). The theory of social action: The correspondence of Alfred Schutz and Talcott Parsons. Ed. by R. Grathoff. Bloomington: Indiana University Press.

Sharrock, W. (2004). What Garfinkel makes of Schutz: The past, present and future of an alternate, asymmetric and inconmmensurable approach to sociology. In Theory \& Science, Vol. 5.1, (found on March 1, 2012 at) http://theoryandscience.icaap.org/content/vol5.1/sharrock.html.

Sharrock, W., \& Anderson, B. (1989). Epistemology: Professional scepticism. In G. Button (Ed.), Ethnomethodology and the human science (pp. 51-76). Cambridge: Cambridge University Press.

Spiegelberg, H. (1982). The phenomenological movement. The Hague/Boston/London: Martinus Nijhoff.

Srubar, I. (1988). Kosmion. Die Genese der pragmatischen Lebenswelttheorie von Alfred Schütz und ihr anthropologischer Hintergrund. Frankfurt/M: Suhrkamp.

Srubar, I. (1998). Phenomenological analysis and its contemporary significance. Alfred Schütz Memorial Lecture. Human Studies, 21, 121-139.

Srubar, I. (2005). The pragmatic theory of the life world as a basis for intercultural comparison. In M. Endress, G. Psathas, \& H. Nasu (Eds.), Explorations of the life-world (pp. 235-266). Dordrecht: Springer.

Srubar, I. (2007). Phänomenologie und soziologische Theorie. Aufsätze zur pragmatischen Lebenswelttheorie. Wiesbaden: VS Verlag für Sozialwissenschaften.

Srubar, I. (2009). Kultur und Semantik. Wiesbaden: VS Verlag für Sozialwissenschaften.

Tyriakian, E. (1965). Existential phenomenology and sociology. American Sociological Review, 30, 674-688.

Tyriakian, E. (1966). Reply to Klaja and Berger. American Sociological Review, 31, $260-264$.

Waksler, F. C. (1969). Is a phenomenological sociology possible?. Unpublished manuscript.

Weber, M. ([1922]1978). Economy and society: An outline of interpretive sociology. Ed. by G. Roth, \& C. Wittich. Berkley: University of California Press.

Woermann, N. (2011). „The phenomenon exhibits its staff as a population”-Die reflexive Akteurskonzeption der Ethnomethodologie. In N. Lüdtke \& H. Matsuzaki (Eds.), Akteur-IndividuumSubjekt: Fragen zu 'Personalität'und 'Sozialität'. Wiesbaden: VS Verlag für Sozialwissenschaften. 